\title{
Teff-Based Complementary Foods Fortified with Soybean and Orange-Fleshed Sweet Potato
}

\author{
Mesfin W. Tenagashaw ${ }^{1,2}$, Glaston M. Kenji ${ }^{1}$, Eneyew T. Melaku ${ }^{3}$, Susanne Huyskens-Keil ${ }^{4} \&$ John N. \\ Kinyuru ${ }^{1}$ \\ ${ }^{1}$ Department of Food Science and Technology, Jomo Kenyatta University of Agriculture and Technology, \\ Nairobi, Kenya \\ ${ }^{2}$ Faculty of Chemical and Food Engineering, Bahir Dar Institute of Technology, Bahir Dar University, Bahir Dar, \\ Ethiopia \\ ${ }^{3}$ Department of Food Science and Applied Nutrition, Addis Ababa Science and Technology University, Addis \\ Ababa, Ethiopia \\ ${ }^{4}$ Division Urban Plant Ecophysiology, Research Group Quality Dynamics/Postharvest Physiology, Faculty of \\ Life Sciences, Humboldt-Universitätzu Berlin, Berlin, Germany \\ Correspondence: Mesfin W. Tenagashaw, Faculty of Chemical and Food Engineering, Bahir Dar Institute of \\ Technology, Bahir Dar University, P.O. Box: 26, Bahir Dar, Ethiopia. Tel: 251-911-319-136. E-mail: \\ mesfinwogayehu@gmail.com
}

Received: September 9, 2016

Accepted: November 18, 2016 Online Published: January 19, 2017

doi:10.5539/jfr.v6n1p112

URL: http://dx.doi.org/10.5539/jfr.v6n1p112

\begin{abstract}
The macronutrient composition of teff-based complementary foods (ComFs) prepared through extrusion cooking and a combination of household-level strategies were evaluated. In extrusion, teff, soybean and orange-fleshed sweet potato were separately processed into their respective flours and composited in a percentage ratio of 70:20:10, respectively. It was then extruded into a complementary food (ComF1). In the case of household-level methods, portions of teff grains separately germinated for 24 and $48 \mathrm{~h}$ were dried and ground to fine flours. Similarly, small portions of soybean grains were separately blanched and roasted; then each were ground to fine flour. Four ComFs (ComF2, ComF3, ComF4, ComF5) were developed by blending flours of ungerminated teff, germinated teff, blanched or roasted soybean and sweet potato using the 70:20:10 ratio. The extrusion cooked ComF had significantly $(\mathrm{p}<0.05)$ high protein $(17.92 \mathrm{~g} / 100 \mathrm{~g})$ while the household-level ComFs had lower protein contents. Energy content of the ComFs ranged from 391.63 to $400.60 \mathrm{kcal} / 100 \mathrm{~g}$. All ComFs met the requirements of protein and energy for 6 to 8 month-old infants. There was no significant difference in the dietary fiber contents of the developed complementary foods despite increased values of insoluble dietary fiber due to germination of teff and blanching or roasting of soybean. The study revealed the potential of developing complementary foods from teff-soybean-sweet potato blends with improved protein and energy contents.
\end{abstract}

Keywords: teff, soybean, sweet potato, extrusion cooking, germination, complementary food

\section{Introduction}

Protein-energy malnutrition (PEM), the silent emergency (Anuonye, Onuh, Egwim, \& Adeyemo, 2010), coupled with other problems such as lack of proper hygiene, improper food preparation and storage practices, infectious diseases and dietary taboos, have continued tempting mankind, especially in the Sub-Saharan Africa, the world's most food-insecure region (Makeri, Bala, \& Kassum, 2011). The problem is even worth among infants and children. According to a recent report, globally 50 million infants were wasted in 2014 (WHO, UNICEF, \& WORLD BANK GROUP, 2015). The problem of PEM begins when a child is introduced to additional foods known as complementary foods. Infants are usually introduced to such transitional foods around the age of six month. According to the FAO/WHO category, those infants from 6 to 8 months of age are very vulnerable to malnutrition (Dewey \& Brown, 2003; WHO/UNICEF, 1998) as the vital nutrients are insufficient to maintain the fast growth and development (Konyole, Kinyuru, Owuor, Kenji, \& Onyango, 2012). At the same time, their biological systems didn't grow fully yet to digest and utilize the foods they receive. Therefore, a special attention is required to the nutritional and functional properties of the complementary foods to be fed to this group of 
infants.

Owing to economic and to some extent dietary taboos, the majority of the poor community in developing countries cannot afford commercially processed and/or fortified complementary foods or animal origin foods to feed their infants. Thus, they usually depend on the locally-available crops (usually cereals) that are not supplemented with legumes and/ or tubers and thus lack the required level of macro- and micro-nutrients. Cereals are a good source of the essential amino acids, methionine and cysteine, and also B-complex vitamins but limiting in lysine. On the other hand, most legumes are rich in lysine but low in sulfur-containing amino acids. Thus, compositing of cereals and legumes results in a good complementarity of a number of nutrients (Mensa-Wilmot, Phillips, Lee, \& Eitenmiller, 2003). Moreover, starchy foods usually produce gruels/porridges of high bulk and not of the desirable (easy-to-swallow) semi-liquid consistency for infants (Nout, unpublished document). Thus, the porridge is usually diluted with more water for easy feeding of infants which in turn results in reduced nutrient and energy density, a problem referred to as nutrient thinning, a cause for poor infant growth and development (Tumwebaze, Gichuhi, Rangari, Tcherbi-Narieh, \& Bovell-Benjamin, 2015). Thus, cereals and legumes cannot effectively be used in complementary food preparation unless modified to some extent. In fact, the use of locally available crops for processing complementary foods for low-income communities through the application of household-level methods has been promoted for decades (Castell-Perez, Griffith, Castell-Perez, \& Griffith, 1998; Elias, 1974; Molina, Braham, \& Bressani, 1983).Therefore, infant foods need proper formulation and processing to improve their nutritional values and consistency as well.

Keeping these facts into account, complementary foods were formulated and processed from a composite of teff, soybean and sweet potato (orange-fleshed) through an industrial-level approach called extrusion cooking, the most common and novel food processing technique (Ramachandra \& Thejaswini, 2015), and a household-level approach referred to as combined strategies, a combination of traditional food processing practices (Hotz \& Gibson, 2007), such as soaking and germination [teff], blanching or roasting and dehulling [soybean], peeling, slicing, blanching [sweet potato], followed by drying and milling of each ingredient and then blending them into a composite flour. The aim of the study was, therefore, to develop complementary foods with improved macronutrient composition and energy content as well.

\section{Materials and Methods}

\subsection{Raw Materials Used for Processing the Complementary Foods}

Red teff [Eragrostis tef (Zucc.) Trotter], soybean [Glycine max (L.) Merr.] and orange-fleshed sweet potato [Ipomoea batatas, $(\mathrm{L}$.) Lam], which will simply be referred to as sweet potato hereafter, were purchased and collected from a local farmers' market, Pawe Agricultural Research Centre and Awassa Agricultural Research Centre, respectively, all from Ethiopia.

\subsection{Processing Approaches of the Complementary Foods}

Two processing approaches were employed to prepare the complementary foods: Industrial-level approach (extrusion cooking) and household-level approach (combined household strategies).

\subsubsection{Industrial-level Approach: Extrusion Cooking}

Before the actual extrusion process was carried out, the raw materials were separately prepared. Teff grain samples were cleaned for some extraneous materials and then washed with tap water until all soil and other undesirable components were removed completely. This was followed by drying the grains in the sun. Similarly, soybean grain samples were manually cleaned, sun dried and dehulled using a laboratory-scale dehulling mill (Alvan Blanch, England). The hulls and undehulled grains were removed by manual sieving. The cleaned teff and soybean grains were ground to fine flour using a local stone mill. Sweet potato tubers were processed according to the method described by Haile, Admassu, \& Fisseha (2015). They were manually washed with tap water, peeled with kitchen knives and sliced into $2 \mathrm{~mm}$ thick slices with a vegetable slicer (model CL30, Robot coupe, Vincennes, France). This was followed by blanching with water at $60{ }^{\circ} \mathrm{C}$ for $5 \mathrm{~min}$ in a water bath. Finally, the slices were spread on racks and dried in a solar drier (Alvan Blanch, Wiltshire, England). The dried potato slices were ground using a laboratory-scale mill (Zhejiang Top Instrument Co., Ltd., China). All the flour samples were packaged in polyethylene bags, labelled and stored in a cold room until the extrusion process was carried out.

The composite flour (described in Section 2.3), the mixture of the three raw materials - teff, soybean and sweet potato - was subjected to extrusion cooking using a pilot-scale twin-screw extruder (model Clextral, BC-21 No. 124, Clextral, Firminy, France). The barrel of the extruder has three $100 \mathrm{~mm}$ long temperature zones fitted with $25 \mathrm{~mm}$ diameter screws. The temperatures of the last two zones were regulated by electrical heating 
(thermocouples) and a water cooling system. The extrusion temperature is controlled by a Eurotherm controller (Eurotherm Ltd., Worthing, U.K.). The composite flour was manually transferred to the feed hopper and then automatically conveyed into the extruder inlet by a twin-screw volumetric feeder (type K-MV-KT20). Tap water was injected into the extruder close to the feed section of the extruder barrel via an inlet port by a metering pump (DKM-Clextral) where the volume of the water is read in units of stroke. A die plate with four circular openings each with a diameter of $3 \mathrm{~mm}$ was used. Both the feeder and the pump were calibrated prior to running the extrusion to determine the set points required for desired flow rates of flour and water, respectively. The extrusion operating conditions were moisture content $(22 \%)$, barrel temperature $\left(120{ }^{\circ} \mathrm{C}\right)$ and screw speed $(200$ $\mathrm{rpm}$ ) selected based on recommended values in the literature and a preliminary experiment. The feed rate was maintained constant at $64 \mathrm{~g} / \mathrm{min}$. Three extrusion runs were performed. Finally, the extrudates were ground using a laboratory-scale mill (Type ZM 100, F. Kurt Retsch GmbH \& Co.KG, Germany) fitted with a $0.5 \mathrm{~mm}$ sieve. The product was a pre-cooked complementary food (ComF1). It was stored in a cold room until laboratory analysis was carried out.

\subsubsection{Household-level Approach: Combined Strategies}

Teff grains were germinated following the method described by Badau, JideanI, \& Nkama (2006) for finger millets with some modifications. The grains were cleaned, washed and rinsed first in distilled water and then in 5\% $(\mathrm{w} / \mathrm{v})$ sodium chloride solution to disinfect them. The grains were then soaked in distilled water for $12 \mathrm{~h}$ using a ratio of 1:3 (grain:water; w/v) in a small plastic bucket. The soaking water was changed in four hours interval. After soaking, the water was drained off and the grains separated into two portions, spread on and covered with a moistened cotton cloth and allowed to germinate at room temperature $\left(25 \pm 2{ }^{\circ} \mathrm{C}\right)$ for two durations, $24 \mathrm{~h}$ and 48 h. At the end of the germination period, the grains were dried in a drying oven (model DHG-9140) at $70{ }^{\circ} \mathrm{C}$ for 8 $\mathrm{h}$. The vegetative parts were discarded by gentle abrasion between hands followed by manual sieving. Soybean grains were processed using two different methods: blanching and roasting. Blanching was conducted according to the method described by Iombor, Umoh, \& Olakumi (2009). The grains were cleaned and then blanched in a boiling pot (model RE300B, Bibby Sterlin Ltd, UK) at $100{ }^{\circ} \mathrm{C}$ for $10 \mathrm{~min}$ (1:5 ratio of seeds to boiling water). The blanched grains were drained, cooled to room temperature, manually dehulled and rinsed to remove the seed coat. The rinsed seeds were then oven dried at $80^{\circ} \mathrm{C}$ for $5 \mathrm{~h}$. Roasting was carried out in a mini baking oven according to the WFP procedure (WFP, 2004), at $170{ }^{\circ} \mathrm{C}$ for $15 \mathrm{~min}$, used in the production of Super Cereal (corn soya blend). The roasted grains were then dehulled using a lab-scale decorticator (Alvan Blanch, England) and the hulls manually removed. The clean teff and soybean grains were finally ground to fine flour using a laboratory-scale mill (Type ZM 100, F. Kurt Retsch GmbH \& Co.KG, Germany). Sweet potato tubers were processed the same way as done for extrusion cooking (Section 2.2.1). Some part of the flour samples were blended to get the final complementary foods (Section 2.3) while a small portion of each of them (germinated teff, blanched soybean, roasted soybean, processed sweet potato) were left for analysis of their composition. All samples were packaged in ziplock polyethylene bags, labelled and stored in a cold room $\left(10^{\circ} \mathrm{C}\right)$ until laboratory analysis.

\subsection{Formulation of the Complementary Foods}

The formulation of the complementary foods was performed using previously published nutrient compositions of the respective raw materials (teff, soybean, sweet potato) so as to approximately meet recommended levels of some vital nutrients (protein, fat, vitamin A) and energy that are suggested in some guidelines for complementary foods for infants and children (Codex Alimentarius Commission, 1991; WFP, 2014). A computer programme known as NutriSurvey for Windows (ProNut-HIV, 2005), was used to approximate the above-mentioned nutrients. The recommendation to use a blend formulation of $75 \%$ cereal and $25 \%$ legume in the formulation of infant complementary foods (Gopaldas, 1991; Plahar, Okezie, \& Gyato, 2003) was taken into account at the beginning of the formulation. The addition of the sweet potato $(10 \%)$ was meant to increase the vitamin A level of the complementary foods as it is a rich source of $\beta$-carotene (precursor of vitamin A) (Amagloh et al., 2012). Accordingly, the percentage proportion of 70:20:10 for teff, soybean and sweet potato, respectively, was found to closely meet the recommendations and thus employed in the formulation of the complementary foods (refer to Table $\mathbf{1}$ ). 
Table 1. Ingredients used in the formulations of the complementary foods with their proportions

\begin{tabular}{|c|c|c|c|}
\hline ComF Formulation & Processing method & Ingredients & Proportion (\%) \\
\hline \multirow{3}{*}{ ComF1 } & \multirow{3}{*}{ Extrusion cooking } & Ungerminated teff & 70 \\
\hline & & Unprocessed soybean & 20 \\
\hline & & Processed sweet potato & 10 \\
\hline \multirow{4}{*}{ ComF2 } & \multirow{4}{*}{ Combined strategies } & Ungerminated teff & 60 \\
\hline & & Germinated teff $-24 \mathrm{~h}$ & 10 \\
\hline & & Blanched soybean & 20 \\
\hline & & Processed sweet potato & 10 \\
\hline \multirow{4}{*}{ ComF3 } & \multirow{4}{*}{ Combined strategies } & Ungerminated teff & 60 \\
\hline & & Germinated teff $-24 \mathrm{~h}$ & 10 \\
\hline & & Roasted soybean & 20 \\
\hline & & Processed sweet potato & 10 \\
\hline \multirow{4}{*}{ ComF4 } & \multirow{4}{*}{ Combined strategies } & Ungerminated teff & 60 \\
\hline & & Germinated teff $-48 \mathrm{~h}$ & 10 \\
\hline & & Blanched soybean & 20 \\
\hline & & Processed sweet potato & 10 \\
\hline \multirow{4}{*}{ ComF5 } & \multirow{4}{*}{ Combined strategies } & Ungerminated teff & 60 \\
\hline & & Germinated teff $-48 \mathrm{~h}$ & 10 \\
\hline & & Roasted soybean & 20 \\
\hline & & Processed sweet potato & 10 \\
\hline
\end{tabular}

ComF- Complementary Food

In case of the industrial-level approach (extrusion cooking), the flours from teff, soybean and sweet potato (Section 2.2.1) were mixed to obtain a composite flour using the above-mentioned proportion, 70:20:10, respectively. This composite flour was finally extruded into ComF1. Some part of each flour was kept for analysis of the ingredients themselves.

Meanwhile, the flour samples prepared using the combined household-level methods (germinated teff, blanched soybean, roasted soybean, processed sweet potato) and also ungerminated teff were blended to produce complementary foods using the same proportion (70:20:10) employed in extrusion cooking. However, in this approach, $10 \%$ of the germinated teff flour was used thus reducing the ungerminated teff to $60 \%$. This was based on the fact that addition of a small quantity of germinated flour (amylase-rich flour) reduces the dietary bulk (gruel viscosity) and increases energy density of a complementary food (Gopaldas, Mehta, Patil, \& Gandhi, 1986; Hossain, Wahed, \& Ahmed, 2015). Moreover, the fact that germination leads to a significant loss of dry matter due to oxidation and leaching, was taken into account (Egli, 2001). In this case, four household-level complementary foods (ComF2, ComF3, ComF4 and ComF5) were developed through blending of the ingredients mentioned above. The mixing was carried out first manually with the help of a ladle in a plastic bowel and then using a laboratory-scale mixer (model B20-B, H.L Universal Mixing Machine, China) for 15 min (at position 2) to ensure homogeneity of the blends.

\subsection{Laboratory Analysis}

The macronutrient composition of the flour samples of each ingredient and those of the developed complementary foods were analyzed according to AOAC International standard methods (AOAC International, 2000). Moisture content was determined by the air-oven method using a hot-air circulating oven (method \#925.09). Ash content was determined through incineration $\left(550^{\circ} \mathrm{C}\right)$ of a known weight of sample in a muffle furnace (method \#923.03). Crude protein was determined by the micro-Kjeldahl method (method \#979.09). The crude protein was obtained by multiplying the corresponding total nitrogen content by a factor of 6.25 (FAO, 2003). Crude fat was determined by extracting a known weight of sample in petroleum ether (boiling point, 40 to $60{ }^{\circ} \mathrm{C}$ ) in a Soxhlet extractor (method \#930.09). Crude fiber content was determined following method \#962.09. Available carbohydrate was obtained by difference while energy was calculated using the Atwater's calorie conversion factors: $4 \mathrm{kcal} / \mathrm{g}$ for crude protein, $9 \mathrm{kcal} / \mathrm{g}$ for crude fat and $4 \mathrm{kcal} / \mathrm{g}$ for available carbohydrate (FAO, 2003). The dietary fiber contents (soluble, insoluble and total) were measured using the enzymatic-gravimetric method as described in the AOAC method \#991.43 and AACC method \#32-05-01 as described in the Megazyme Assay Procedure: K-TDFR 06/14 (Megazyme International, 2013). The water-soluble and water-insoluble fractions were determined through digestion with enzymes. A $0.5 \mathrm{~g}$ of the sample was weighed followed by addition of $50 \mathrm{ml}$ of phosphate buffer. Then enzymatic hydrolysis of starch and protein was carried out through a sequential addition of three enzymes: $\alpha$-amylase $\left(50 \mu \mathrm{l}, 95^{\circ} \mathrm{C}, 30 \mathrm{~min}, \mathrm{pH} 6.0\right)$, protease $\left(100 \mu \mathrm{l}, 60^{\circ} \mathrm{C}, 30 \mathrm{~min}\right.$, $\mathrm{pH}$ 7.5) and amyloglucosidase $\left(200 \mu \mathrm{l}, 60^{\circ} \mathrm{C}, 30 \mathrm{~min}, \mathrm{pH} 4.5\right)$. Insoluble dietary fiber was recovered by 
filtration using celite as the filter aid. Soluble dietary fiber was then precipitated from the filtrate with $15 \mathrm{ml}$ each of $78 \%$ ethanol, $96 \%$ ethanol and acetone. The fiber values were corrected for indigestible protein $(\mathrm{N} \mathrm{x} \mathrm{6.25)}$ through determination by the Kjeldahl method and ash which was determined by ignition at $525{ }^{\circ} \mathrm{C}$ for $8 \mathrm{~h}$. The total dietary fiber was calculated as the sum of the soluble and insoluble fractions.

\subsection{Statistical Analysis}

One-way analysis of variance (ANOVA) was applied to the data by the use of IBM SPSS for Windows (version 21). The significant difference was analyzed by Tukey's HSD (honest significant difference) test. The level of significance was set at $5 \%$ probability level.

\section{Results and Discussion}

The results for macronutrient composition of the ingredients used for formulating the complementary foods are shown in Table 2. The moisture and ash contents were in the range of 2.51 to 7.36 and 2.12 to $5.03 \mathrm{~g} / 100 \mathrm{~g}$, respectively. The ash content in a given food sample indicates the level of minerals present (Kavitha \& Parimalavalli, 2014). It was affected by the processes employed. Germination of teff, both for 24 and $48 \mathrm{~h}$, had significantly $(\mathrm{p}<0.05)$ decreased the ash content. As it was found out in an earlier research, this decrease might be due to leaching of minerals during washing and soaking of the grains (Inyang \& Zakari, 2008). However, ash content of soybean significantly increased due to blanching (Ugwuona, Awogbenja, \& Ogara, 2012) and roasting (Kavitha \& Parimalavalli, 2014) which could be due to volatilization of the organic matter. As expected, significantly high crude protein $(\mathrm{p}<0.05)$ was found for the unprocessed soybean $(34.57 \mathrm{~g} / 100 \mathrm{~g})$, very close to that reported by Anuonye et al. (2010). The blanched or roasted soybean also gave slightly higher protein contents of 35.59 and $36.22 \mathrm{~g} / 100 \mathrm{~g}$, respectively. The lowest value of protein was that of the sweet potato (5.70 $\mathrm{g} / 100 \mathrm{~g}$ ) which is nearly similar to what was reported by Omodamiro et al. (2013) for some varieties of sweet potato. A similar trend was also observed for crude fat. The highest crude fat $(22.99 \mathrm{~g} / 100 \mathrm{~g})$ was found in unprocessed soybean which agrees with the available literature (Anuonye et al., 2010) whereas the lowest was recorded for sweet potato $(0.84 \mathrm{~g} / 100 \mathrm{~g})$. Germination of teff, both for 24 and $48 \mathrm{~h}$, had significantly $(\mathrm{p}<0.05)$ decreased the crude fat contents. Similar results were found by Megat Rusydi, Noraliza, Azrina, \& Zulkhairi (2011) for some legumes and rice varieties. The decrease in fat content might be due to the increased activities of the lipolytic enzymes which hydrolyze fats to fatty acids and glycerol during germination (Kavitha \& Parimalavalli, 2014).The fatty acids are further oxidized to carbon dioxide and water to generate energy for the germination process (Hahm, Park, \& Martin Lo, 2009). Blanching or roasting of soybean had also significantly $(\mathrm{p}<0.05)$ reduced fat contents which could be due to loss of some fat during the heating process; especially, the reduction caused by roasting was very high.

Table 2. Macronutrient composition of the ingredients used in the formulations of complementary foods

\begin{tabular}{llcccccc}
\hline \multirow{2}{*}{ ComF Ingredients } & \multicolumn{5}{c}{ Macronutrient Composition $(\mathrm{g} / 100 \mathrm{~g})$} \\
\cline { 3 - 8 } & & Moisture & Ash & Crude Protein & Crude Fat & Crude Fiber & Available CHO \\
\hline \multirow{3}{*}{ Teff } & Ungerminated & $6.35 \pm 0.12^{\mathrm{d}}$ & $3.28 \pm 0.03^{\mathrm{bc}}$ & $7.80 \pm 0.05^{\mathrm{ab}}$ & $5.71 \pm 0.84^{\mathrm{c}}$ & $3.87 \pm 0.27^{\mathrm{a}}$ & $79.34 \pm 0.85^{\mathrm{c}}$ \\
& Germinated-24 h & $4.87 \pm 0.69^{\mathrm{c}}$ & $2.12 \pm 0.25^{\mathrm{a}}$ & $10.40 \pm 0.76^{\mathrm{b}}$ & $2.72 \pm 0.28^{\mathrm{ab}}$ & $4.98 \pm 0.49^{\mathrm{b}}$ & $79.78 \pm 0.65^{\mathrm{c}}$ \\
& Germinated-48 h & $4.53 \pm 0.05^{\mathrm{c}}$ & $2.24 \pm 0.19^{\mathrm{a}}$ & $8.01 \pm 0.37^{\mathrm{b}}$ & $2.50 \pm 0.13^{\mathrm{a}}$ & $5.19 \pm 0.06^{\mathrm{b}}$ & $82.05 \pm 0.07^{\mathrm{c}}$ \\
\hline \multirow{3}{*}{ Soybean } & Unprocessed & $3.16 \pm 0.32^{\mathrm{ab}}$ & $3.08 \pm 0.02^{\mathrm{b}}$ & $34.57 \pm 0.83^{\mathrm{c}}$ & $22.99 \pm 1.11^{\mathrm{e}}$ & $5.34 \pm 0.70^{\mathrm{b}}$ & $34.02 \pm 1.81^{\mathrm{a}}$ \\
& Blanched & $3.48 \pm 0.19^{\mathrm{b}}$ & $3.61 \pm 0.09^{\mathrm{c}}$ & $35.59 \pm 2.04^{\mathrm{c}}$ & $10.22 \pm 1.05^{\mathrm{d}}$ & $5.35 \pm 0.29^{\mathrm{b}}$ & $45.22 \pm 2.76^{\mathrm{b}}$ \\
& Roasted & $2.51 \pm 0.43^{\mathrm{a}}$ & $5.03 \pm 0.11^{\mathrm{d}}$ & $36.22 \pm 0.76^{\mathrm{c}}$ & $4.57 \pm 0.31^{\mathrm{bc}}$ & $5.76 \pm 0.33^{\mathrm{b}}$ & $48.43 \pm 1.00^{\mathrm{b}}$ \\
\hline Sweet potato & Processed & $7.36 \pm 0.03^{\mathrm{e}}$ & $3.61 \pm 0.04^{\mathrm{c}}$ & $5.70 \pm 0.31^{\mathrm{a}}$ & $0.84 \pm 0.04^{\mathrm{a}}$ & $3.76 \pm 0.17^{\mathrm{a}}$ & $86.09 \pm 0.18^{\mathrm{d}}$ \\
\hline$P$-value & & $<0.001$ & $<0.001$ & $<0.001$ & $<0.001$ & $<0.001$ & $<0.001$ \\
\hline
\end{tabular}

Values are mean \pm standard deviation of three independent determinations on dry matter basis. The different superscripts in the same column with different letters are significantly different $(\mathrm{p}<0.05)$.

CHO - Carbohydrate

Crude fiber contents ranged from 3.76 for sweet potato to $5.76 \mathrm{~g} / 100 \mathrm{~g}$ for roasted soybean. There was a significant increase due to germination of teff which could be, as reported by Megat et al. (2016), because of synthesis of new polysaccharides during the process. Only a slight change was observed from blanching or roasting of soybean. The sweet potato gave the highest value of carbohydrate $(86.09 \mathrm{~g} / 100 \mathrm{~g})$, which is in good agreement with a previous report (Oke \& Workneh, 2013) followed by those of $48 \mathrm{~h}$ and $24 \mathrm{~h}$ germinated teff with 82.05 and $79.78 \mathrm{kcal} / 100 \mathrm{~g}$, respectively. The significant increase in the carbohydrate content of soybean after blanching or roasting could be due to starch hydrolysis to simple sugars. This increase in carbohydrate content is advantageous in infant feeding from a number of perspectives. On one hand, the molecules are more 
soluble in water, and on the other, the porridges from the resulting final blends would be of lower viscosity and thus need less water for dilution thereby preventing nutrient and energy thinning (Amagloh et al., 2013).

Similarly, the macronutrient composition of the complementary foods are presented in Table 3. No significant difference $(p>0.05)$ was found in the moisture and crude fiber contents of the complementary foods, but they are lying within the range prescribed for complementary foods (Codex Alimentarius Commission, 1991; WFP, 2014). The industrial-level complementary food (ComF1) had the lowest ash content ( $3.20 \mathrm{~g} / 100 \mathrm{~g})$ compared to those of the household-level complementary foods (ComF2 to ComF5). Minerals are heat stable and thus unlikely to be lost by the extrusion process (Singh, Gamlath, \& Wakeling, 2007). Thus the reduction in the mineral content of ComF1 could probably be because of physical loss of some minerals during the extrusion process as suggested by Reddy \& Love (1999) who reported that milling and extrusion can cause physical removal of minerals during processing. The highest ash contents were obtained for ComF3 (3.55 g/100 g) and ComF5 (3.56 g/100 g) which could be due to the increased ash contents in the roasted soybean (Table 2).

The industrial-level complementary food $(\mathrm{ComF} 1)$ had significantly higher $(\mathrm{p}<0.05)$ protein content $(17.92$ $\mathrm{g} / 100 \mathrm{~g}$ ). Obatolu et al. (2000) reported that such an increase in protein content could be because of denaturation of protein molecules as a result of the high extrusion temperature and that this makes the protein molecules more susceptible to proteolysis thereby improving protein digestibility. There is no significant difference $(p>0.05)$ in the protein content among the household-level complementary foods, the values ranging from 13.30 to 13.53 $\mathrm{g} / 100 \mathrm{~g}$. However, all the complementary foods can closely meet the recommended protein content $(15 \mathrm{~g} / 100 \mathrm{~g})$ (Codex Alimentarius Commission, 1991). The fat contents of all complementary foods were within the range prescribed for complementary foods $(6 \mathrm{~g} / 100 \mathrm{~g})$ as described in the WFP technical specifications for the manufacture of Super Cereal (Corn-Soya-Blend) (WFP, 2014). It can be seen that the fat contents are safer both from nutrition and shelf stability point of view. The fat content of ComF1 $(6.22 \mathrm{~g} / 100)$ was significantly higher $(\mathrm{p}<0.05)$ compared to those of ComF3 (4.69 g/100) and ComF5 (4.68 g/100 g) while it had no difference from those of ComF2 (5.83 g/100) and ComF4 (5.80 g/100).

Table 3. Macronutrient composition $(\mathrm{g} / 100 \mathrm{~g})$ and energy content $(\mathrm{kcal} / 100 \mathrm{~g})$ of the developed complementary foods

\begin{tabular}{|c|c|c|c|c|c|c|c|}
\hline \multirow[b]{2}{*}{$\begin{array}{c}\text { ComF } \\
\text { Formulation }\end{array}$} & \multicolumn{7}{|c|}{ Macronutrient Composition and Energy Content } \\
\hline & Moisture & Ash & Crude Protein & Crude Fat & Crude Fiber & $\begin{array}{c}\text { Available } \\
\mathrm{CHO}\end{array}$ & Gross Energy \\
\hline ComF1 & $\begin{array}{c}6.53 \pm \\
0.93^{\mathrm{a}}\end{array}$ & $\begin{array}{c}3.20 \pm \\
0.03^{\mathrm{a}}\end{array}$ & $\begin{array}{c}17.92 \pm \\
0.41^{\mathrm{b}}\end{array}$ & $\begin{array}{c}6.22 \pm \\
0.59^{\mathrm{b}}\end{array}$ & $\begin{array}{c}4.43 \pm \\
0.34^{\mathrm{a}}\end{array}$ & $\begin{array}{c}68.23 \pm \\
0.81^{\mathrm{a}}\end{array}$ & $\begin{array}{c}400.60 \pm \\
3.49^{\mathrm{b}}\end{array}$ \\
\hline ComF2 & $\begin{array}{c}5.77 \pm \\
0.05^{\mathrm{a}}\end{array}$ & $\begin{array}{l}3.27 \pm \\
0.01^{\mathrm{b}}\end{array}$ & $\begin{array}{c}13.41 \pm \\
0.49^{\mathrm{a}}\end{array}$ & $\begin{array}{l}5.83 \pm \\
0.47^{\text {ab }}\end{array}$ & $\begin{array}{c}4.27 \pm \\
0.11^{\mathrm{a}}\end{array}$ & $\begin{array}{c}73.23 \pm \\
0.35^{\mathrm{b}}\end{array}$ & $\begin{array}{c}398.99 \pm \\
2.23^{\mathrm{ab}}\end{array}$ \\
\hline ComF3 & $\begin{array}{c}5.58 \pm \\
0.17^{\mathrm{a}}\end{array}$ & $\begin{array}{c}3.55 \pm \\
0.02^{\mathrm{c}}\end{array}$ & $\begin{array}{c}13.53 \pm \\
0.09 \mathrm{a}\end{array}$ & $\begin{array}{c}4.69 \pm \\
0.53 \mathrm{a}\end{array}$ & $\begin{array}{c}4.35 \pm \\
0.07^{\mathrm{a}}\end{array}$ & $\begin{array}{c}73.87 \pm \\
0.59^{\mathrm{b}}\end{array}$ & $\begin{array}{c}391.88 \pm \\
2.51^{\mathrm{a}}\end{array}$ \\
\hline ComF4 & $\begin{array}{c}5.70 \pm \\
0.04^{\mathrm{a}}\end{array}$ & $\begin{array}{c}3.27 \pm \\
0.01^{\mathrm{b}}\end{array}$ & $\begin{array}{c}13.17 \pm \\
0.43^{\mathrm{a}}\end{array}$ & $\begin{array}{l}5.80 \pm \\
0.51^{\mathrm{ab}}\end{array}$ & $\begin{array}{c}4.29 \pm \\
0.14^{\mathrm{a}}\end{array}$ & $\begin{array}{c}73.46 \pm \\
0.32^{\mathrm{b}}\end{array}$ & $\begin{array}{c}398.74 \pm \\
2.55^{\mathrm{ab}}\end{array}$ \\
\hline ComF5 & $\begin{array}{c}5.50 \pm \\
0.01^{\mathrm{a}} \\
\end{array}$ & $\begin{array}{c}3.56 \pm \\
0.01^{\mathrm{c}} \\
\end{array}$ & $\begin{array}{c}13.30 \pm \\
0.16^{\mathrm{a}} \\
\end{array}$ & $\begin{array}{c}4.68 \pm \\
0.57 \mathrm{a} \\
\end{array}$ & $\begin{array}{c}4.37 \pm \\
0.08^{\mathrm{a}} \\
\end{array}$ & $\begin{array}{c}74.10 \pm \\
0.66^{\mathrm{b}}\end{array}$ & $\begin{array}{c}391.63 \pm \\
2.82^{\mathrm{a}}\end{array}$ \\
\hline$P$-value & 0.078 & $<0.001$ & $<0.001$ & 0.015 & 0.823 & $<0.001$ & 0.005 \\
\hline Reference value & $10^{\alpha}$ & $4.1^{\alpha}$ & $15^{\delta}$ & $6^{\alpha}$ & $5^{\delta}$ & $60-75^{\mu}$ & $400^{\delta}$ \\
\hline
\end{tabular}

Values are mean \pm standard deviation of three independent determinations on dry matter basis. The different superscripts in the same column with different letters are significantly different $(\mathrm{p}<0.05)$.

${ }^{\alpha}$ (WFP, 2014); ${ }^{\delta}$ (Codex Alimentarius Commission, 1991); ${ }^{\mu}$ (Amagloh, 2012)

A high fat content in a complementary food provides more energy to the infant. However, if it exceeds the desirable level, it would be disadvantageous for stability of the product as the unsaturated fatty acids are vulnerable to oxidative rancidity (Lohia \& Udipi, 2015) that would shorten its shelf life. On the other hand, a lower fat content in complementary foods results in a poor energy density which is an issue of a big concern in complementary feeding (Suri, Tano-Debrah, \& Ghosh, 2014). For 6 to 8 month-old infants in low-income countries, the required percentage of energy from fat in complementary foods is $0-34 \%$ depending on the level of breast milk intake and the fat content of the breast milk. Fat is important in the diets of infants and young children because it provides essential fatty acids, facilitates absorption of fat soluble vitamins, and enhances dietary energy density and sensory qualities (Pan American Health Organization (PAHO) and World Health Organization (WHO), 2001). The carbohydrate contents of the complementary foods are in the range of 68.23 
$\mathrm{g} / 100 \mathrm{~g}$ to $74.10 \mathrm{~g} / 100$ within the range recommended (60-75 g/100) for infants and children (Amagloh, 2012). The gross energy contents of all complementary foods are very close to that recommended in the Codex standard (400 kcal/100 g) (Codex Alimentarius Commission, 1991). The lower energy contents of comF3 and ComF5 are results of the corresponding lower values of crude fat.

The dietary fiber contents of the flour samples used in the development of the complementary foods are presented in Table 4. Dietary fibers are parts of plant materials that are not digested by the endogenous secretions of the human digestive tracts (Azizah \& Zainon, 1997). They include cellulose, non-cellulosic polysaccharides such as hemicellulose, pectic substances, gums, mucilages and a non-carbohydrate component lignin and are subdivided into water-soluble and water-insoluble fractions (Dhingra, Michael, \& Rajput, 2012; Ötles \& Ozgoz, 2014). Soluble fibers dissolve in water and form viscous gels. They bypass the digestion of the small intestine and are easily fermented by the microflora of the large intestine. However, insoluble fibers do not dissolve in water and fermentation is limited (Ötles \& Ozgoz, 2014).

No significant difference $(\mathrm{p}>0.05$ ) was found in the soluble dietary fiber (SDF) contents of the ingredients used for developing the complementary foods. Very low SDF were obtained ranging from 0.55 to $1.35 \mathrm{~g} / 100 \mathrm{~g}$. That is, both germination of teff and blanching or roasting of soybean didn't significantly affect the SDF values. The highest SDF $(3.57 \mathrm{~g} / 100 \mathrm{~g})$ was obtained for sweet potato which is an indication that orange-fleshed sweet potato is a rich source of SDF. This finding agrees with the work of Astawan \& Widowati (2011) who reported dietary fibers contents for different varieties of sweet potato. The values for insoluble dietary fiber (IDF) varied to some extent though there were no detectable trends. Germination of teff for $48 \mathrm{~h}$ and blanching of soybean had significantly $(\mathrm{p}<0.05)$ increased the IDF, 10.26 and $16.74 \mathrm{~g} / 100 \mathrm{~g}$, respectively. A similar trend of increment in dietary fiber values were obtained for some germinated legumes in a previous study (Benitez et al., 2013). The increase in dietary fiber after germination is, according to a previous report, due to synthesis of new polysaccharides (Megat et al., 2016). There was no significant difference in the IDF contents of the unprocessed soybean $(11.50 \mathrm{~g} / 100 \mathrm{~g})$ and roasted soybean $(12.22 \mathrm{~g} / 100 \mathrm{~g})$ whereas the blanched soybean had significantly higher IDF content (17.30 g/100 g). A similar trend was observed by Azizah \& Zainon (1997) for boiled soybean. They reported that boiling significantly increased the IDF content of soybean and this may be attributed to the production of Maillard reaction products due to the high protein content of soybean. The lowest IDF value was that of sweet potato $(5.59 \mathrm{~g} / 100 \mathrm{~g})$. A similar trend, as for the IDF, was found for the total dietary fiber (TDF) of the flour samples. The lowest TDF was obtained for the ungerminated teff $(8.63 \mathrm{~g} / 100 \mathrm{~g})$ whereas the highest was that of the blanched soybean $(17.30 \mathrm{~g} / 100 \mathrm{~g})$.

Table 4. Soluble, insoluble and total dietary fiber contents of the ingredients

\begin{tabular}{llccc}
\hline \multirow{2}{*}{ ComF Ingredient } & \multicolumn{3}{c}{ Dietary Fiber $(\mathrm{g} / 100 \mathrm{~g})$} \\
\cline { 3 - 5 } & & Soluble & Insoluble & Total \\
\hline \multirow{3}{*}{ Teff } & Ungerminated & $0.74 \pm 0.25^{\mathrm{a}}$ & $7.89 \pm 0.50^{\mathrm{b}}$ & $8.63 \pm 0.77^{\mathrm{a}}$ \\
& Germinated-24 h & $0.56 \pm 0.04^{\mathrm{a}}$ & $8.29 \pm 0.15^{\mathrm{bc}}$ & $8.85 \pm 0.19^{\mathrm{ab}}$ \\
& Germinated-48 $\mathrm{h}$ & $0.55 \pm 0.09^{\mathrm{a}}$ & $10.26 \pm 0.99^{\mathrm{cd}}$ & $10.81 \pm 0.90^{\mathrm{bc}}$ \\
\hline \multirow{3}{*}{ Soybean } & Unprocessed & $0.93 \pm 0.05^{\mathrm{a}}$ & $11.50 \pm 0.63^{\mathrm{d}}$ & $12.43 \pm 0.70^{\mathrm{cd}}$ \\
& Blanched & $0.57 \pm 0.12^{\mathrm{a}}$ & $16.74 \pm 0.14^{\mathrm{e}}$ & $17.30 \pm 0.03^{\mathrm{e}}$ \\
& Roasted & $1.35 \pm 0.07^{\mathrm{a}}$ & $12.22 \pm 0.15^{\mathrm{d}}$ & $13.57 \pm 0.07^{\mathrm{d}}$ \\
\hline Sweet potato & Processed & $3.57 \pm 0.47^{\mathrm{b}}$ & $5.59 \pm 0.34^{\mathrm{a}}$ & $9.15 \pm 0.13^{\mathrm{ab}}$ \\
\hline$P$-value & & $<0.001$ & $<0.001$ & $<0.001$ \\
\hline
\end{tabular}

Values are mean \pm standard deviation of duplicate determinations on dry matter basis. The different superscripts in the same column with different letters are significantly different $(\mathrm{p}<0.05)$.

$\mathrm{SDF}=$ Soluble Dietary Fiber, IDF $=$ Insoluble Dietary Fiber, TDF $=$ Total Dietary Fiber

The dietary fiber results for the developed complementary foods are presented in Table 5. All soluble, insoluble and total dietary fiber contents didn't show significant variation $(\mathrm{p}>0.05)$ among all the complementary foods. The SDF values were in the range of 0.97 to $1.13 \mathrm{~g} / 100 \mathrm{~g}$ and are very low compared to the 1:4 or 1:3 (soluble to insoluble dietary fiber) recommendation (Williams, 1995) whereas the IDF values ranged from 8.23 to 9.66 $\mathrm{g} / 100 \mathrm{~g}$ which is largely a contribution from the soybean ingredients and also to some extent from teff components. The TDF values are close to the recommended value of about $10 \mathrm{~g} / 100 \mathrm{~g}$ (Egli, 2001; Williams, 1995 ) which represents a safe and tolerable level for most children. This higher level of TDF could be attributed to the higher IDF values in soybean and teff grains (Table 4). 
Table 5. Soluble, insoluble and total dietary fiber contents of the complementary foods

\begin{tabular}{lccc}
\hline \multirow{2}{*}{ ComF Formulation } & \multicolumn{3}{c}{ Dietary Fiber $(\mathrm{g} / 100 \mathrm{~g})$} \\
\cline { 2 - 4 } & Soluble & Insoluble & Total \\
\hline ComF1 & $1.30 \pm 0.20^{\mathrm{a}}$ & $8.23 \pm 1.25^{\mathrm{a}}$ & $9.53 \pm 1.05^{\mathrm{a}}$ \\
ComF2 & $0.97 \pm 0.12^{\mathrm{a}}$ & $9.47 \pm 0.28^{\mathrm{a}}$ & $10.44 \pm 0.41^{\mathrm{a}}$ \\
ComF3 & $1.13 \pm 0.09^{\mathrm{a}}$ & $8.57 \pm 0.36^{\mathrm{a}}$ & $9.69 \pm 0.44^{\mathrm{a}}$ \\
ComF4 & $0.97 \pm 0.14^{\mathrm{a}}$ & $9.66 \pm 0.21^{\mathrm{a}}$ & $10.63 \pm 0.35^{\mathrm{a}}$ \\
ComF5 & $1.13 \pm 0.10^{\mathrm{a}}$ & $8.76 \pm 0.26^{\mathrm{a}}$ & $9.89 \pm 0.37^{\mathrm{a}}$ \\
\hline Reference value & --- & --- & $10^{\beta}$ \\
\hline$P$-value & 0.255 & 0.245 & 0.378 \\
\hline
\end{tabular}

Values are mean \pm standard deviation of duplicate determinations on dry matter basis. The different superscripts in the same column with different letters are significantly different $(\mathrm{p}<0.05)$.

${ }^{\beta}($ Egli, 2001)

According to earlier reports (Agostoni, Riva, \& Giovannini, 1995; Brooks, Mongeau, Deeks, \& Lampi, 2006), dietary fiber has a number of health benefits during early and future lives of a child. Although there are no specific recommendations as such, both soluble and insoluble fibers are strongly associated with improving health issues and are recommended to be taken in generous amounts (Williams, 1995). Soluble fibers serve as substrate for health-promoting bacteria (lactobacilli and bifidobacteria) (Anderson et al., 2009; Gustafson \& Anderson, 1994). They also increase fecal mass and their fermentation byproducts have a laxative effect (Williams, 1995). Insoluble fibers soften and enlarge the stool in the colon by absorbing water, increasing bacterial proliferation and gas reduction all of which resulting in decreasing stool transit time and increasing frequency of bowel movements. Generally, consumption of foods with good dietary fiber content are associated with a higher satiety, lower incidences of obesity and improved micronutrient intake in children (Brooks et al., 2006). Thus, it is important that infants be fed with weaning foods that contain enough dietary fibers so that tastes and eating patterns become established as early as possible (Brooks et al., 2006). However, despite all these benefits of dietary fiber, presence of excess dietary fiber in weaning foods may have undesirable effects such as lower caloric density and irritation of the gut mucosa (Asma, El Fadil, \& El Tinay, 2006). Dietary fiber may also prevent bioavailability of minerals as high-fiber foods may contain phytates and oxalates that can form insoluble compounds with minerals, thereby preventing normal absorption and metabolism (Williams, 1995). However, decreased bioavailability of minerals is likely to occur only when mineral intake is inadequate (Asma et al., 2006). Nonetheless, the desirable or optimal level of dietary fiber content that should be present in the foods of infants and children is not yet clearly defined as there are varying reports in the literature showing the need for further investigations on the subject (Egli, 2001).

\section{Conclusion}

In low-income countries, the complementary feeding period has been observed to be a very vulnerable period in one's life. It is the period when the PEM disorder begins and affects the normal growth and development of an infant. In addition to the lack of protein- and energy-rich foods, there are a number of factors contributing to the problem and the consequences are multidimensional ultimately affecting the socio-economic aspects of a given community and the nation at large.

The problem of malnutrition among infants and children in resource-poor communities can be tackled through appropriately feeding the infant using locally available materials and practices. Complementary foods prepared from blends of teff, soybean and orange-fleshed sweet potato, either through extrusion cooking or a combination of household practices (soaking, germination, blanching, roasting, dehulling, milling, blending) can meet recommended levels of protein, energy and other nutrients to a 6 to 8 month-old infant. Both the compositing of the raw materials and processes employed (industrial level and household level) resulted in improved macronutrient compositions of the developed complementary foods. Rural communities in the Sub-Saharan Africa, especially Ethiopia, can acquire a multitude of benefits by using the composite flours to prepare complementary foods for their infants and children as the raw materials are locally available and the processing approaches are easily applicable at home- and/or community-level.

\section{Acknowledgement}

We are thankful to DAAD/RUFORUM for the scholarship awarded to Mesfin Tenagashaw under which this research was carried out. We also wish to thank Bahir Dar Institute of Technology (Bahir Dar University) and Jomo Kenyatta University of Agriculture and Technology where the complementary foods were processed and 
analyzed, respectively. The kind assistance received from Dr. Susanne Huyskens-Keil, Humboldt-Universität zu Berlin, and also the generous cooperation of iASP (Institute for Agricultural and Urban Ecological Projects), Berlin, Germany, to conduct the dietary fiber analysis, are all highly acknowledged.

\section{References}

\section{References}

Agostoni, C., Riva, E., \& Giovannini, M. (1995). Dietary fiber in weaning foods of young children. Pediatrics, 96(5 Pt 2), 1002-1005.

Amagloh, F. K. (2012). Sweetpotato-based complementary food for infants in Ghana (Unpublished doctoral dissertation). Massey University, Palmerston North, New Zealand.

Amagloh, F. K., Hardacre, A., Utukumira, A. N., Weber, J. L., Brough, L., \& Coad, J. (2012). A household-level sweet potato-based infant food to complement vitamin A supplementation initiatives. Maternal and Child Nutrition, 8(4), 512-521. https://doi.org/10.1111/j.1740-8709.2011.00343.x

Amagloh, F. K., Mutukumira, A. N., Brough, L., Weber, J. L., Hardacre, A., \& Coad, J. (2013). Carbohydrate composition, viscosity, solubility, and sensory acceptance of sweetpotato- and maize-based complementary foods. Food and Nutrition Research, 57, 1-9.

Anderson, J. W., Baird, P., Jr, R. H. D., Ferreri, S., Knudtson, M., Koraym, A., ... Williams, C. L. (2009). Health benefits of dietary fiber, Nutrition Reviews, 67(4), 188-205. https://doi.org/10.1111/j.1753-4887.2009.00189.x

Anderson, J. W., Smith B. M., \& Gustafson, N. J. (1994). Health benefits and practical aspects of high-fiber diets. The American Journal of Clinical Nutrition, 59(Suppl), 1242S-7S.

Gopaldas, T. (1991). Technologies to improve weaning foods in developing countries. Indian Pediatrics, 28(March), 217-221.

Anuonye, J. C., Onuh, J. O., Egwim, E., \& Adeyemo, S. O. (2010). Nutrient and antinutrient composition of extruded acha/soybean blends. Journal of Food Processing and Preservation, 34(2010), 680-691. https://doi.org/10.1111/j.1745-4549.2009.00425.x

AOAC International. (2000). Official Methods of Analysis (18th ed.). Washington, DC: Association of Official Analytical Chemists.

Asma, M. A., El Fadil, E. B., \& El Tinay, A. H. (2006). Development of weaning food from sorghum supplemented with legumes and oil seeds. Food and Nutrition Bulletin, 27(1), 26-34.

Astawan, M., \& Widowati, S. (2011). Evaluation of nutrition and glycemic index of sweet potatoes and its appropriate processing to hypoglycemic foods. Indonesian Journal of Agricultural Science 12(1), 40-46.

Azizah, A., \& Zainon, H. (1997). Effect of processing on dietary fiber content of cereals and pulses. Malaysian Journal of Nutrition, 3, 131-136.

Badau, M. H., JideanI, I. A., \& Nkama, I. (2006). Rheological behaviour of weaning food formulations as affected by addition of malt. International Journal of Food Science and Technology, 41(10), 1222-1228. https://doi.org/10.1111/j.1365-2621.2006.01189.x

Benitez, V., Cantera, S., Aguilera, Y., Molla, E., Esteban, R. M., Diaz, M. F., \& Martin-Cabrejas, M. A. (2013). Impact of germination on starch, dietary fiber and physicochemical properties in non-conventional legumes. Food Research International, 50(1), 64-69. https://doi.org/10.1016/j.foodres.2012.09.044

Bressani, R., Murillo, B. \& Elias, L. G. (1974). Whole soybeans as a means of increasing and calories in maize-based diet and protein. Journal of Food Science, 39, 577-580.

Brooks, S. P. J., Mongeau, R., Deeks, J. R., \& Lampi, B. J. (2006). Dietary fibre in baby foods of major brands sold in Canada. Journal of Food Composition and Analysis, 19, 59-66. https://doi.org/10.1016/j.jfca.2005.02.002

Castell-Perez, M. E., Griffith, L. D., Castell-Perez, M. E., \& Griffith, M. E. (1998). Effects of blend and processing method on the nutritional quality of weaning foods made from select cereals and legumes. Cereal Chemistry, 75(1), 105-112. https://doi.org/10.1094/CCHEM.1998.75.1.105

Codex Alimentarius Commission. (1991). Guidelines on formulated supplementary foods for older infants and young children: CAC/GL 08-1991. Rome, Italy.

Dewey, K. G., \& Brown, K. H. (2003). Update on technical issues concerning complementary feeding of young children in developing countries and implications for intervention programs. Food and Nutrition Bulletin, 
24(1), 5-28. Retrieved from

http://www.who.int/entity/mip/2003/other_documents/en/FNB_24-1_WHO.pdf\#page=5

Dhingra, D., Michael, M., \& Rajput, H. (2012). Dietary fibre in foods: a review. Journal of Food Science and Technology, 49(3), 255-266. https://doi.org/10.1007/s13197-011-0365-5

Egli, I. M. (2001). Traditional food processing methods to increase bioavailability from cereal and legume based weaning foods (Unpublished doctoral dissertation). Swiss Federal Institute of Technology, Zurich, Switzerland.

FAO. (2003). Food energy - Methods of analysis and conversion factors: Report of a technical workshop, Rome, 2002. FAO Food and Nutrition Paper No. 77. Rome. Retrieved from http://www.fao.org/docrep/006/y5022e/y5022e00.htm\#Contents/nftp://ftp.fao.org/docrep/fao/006/y5022e/y 5022e00.pdf

Gopaldas, T., Mehta, P., Patil, A., \& Gandhi, H. (1986). Studies on reduction in viscosity of thick rice gruels with small quantities of an amylase-rich cereal malt. Food and Nutrition Bulletin, 8(4).

Hahm, T.-S., Park, S.-J., \& Martin Lo, Y. (2009). Effects of germination on chemical composition and functional properties of sesame (Sesamum indicum L.) seeds. Bioresource Technology, 100(4), 1643-7. https://doi.org/10.1016/j.biortech.2008.09.034

Haile, F., Admassu, S., \& Fisseha, A. (2015). Effects of pre-treatments and drying methods on chemical composition, microbial and sensory qualities of orange-fleshed sweet potato flour and porridge. American Journal of Food Science and Technology, 3(3), 82-88. https://doi.org/10.12691/ajfst-3-3-5

Hossain, M. I., Wahed, M. A., \& Ahmed, S. (2015). Increased food intake after the addition of amylase-rich flour to supplementary food for malnourished children in rural communities of Bangladesh. Food and Nutrition Bulletin, 26(4), 323-329.

Hotz, C., \& Gibson, R. S. (2007). Traditional food-processing and preparation practices to enhance the bioavailability of micronutrients in plant-based diets. The Journal of Nutrition, 137(4), 1097-1100.

Inyang, C. U., \& Zakari, U. M. (2008). Effect of germination and fermentation of pearl millet on proximate chemical and sensory properties of instant "Fura" - A Nigerian cereal food. Pakistan Journal of Nutrition, 7(1), 9-12. https://doi.org/10.3923/pjn.2008.9.12

Iombor, T. T. T., Umoh, E. J. E., \& Olakumi, E. (2009). Proximate composition and organoleptic properties of complementary food formulated from millet (Pennisetum psychostachynum), soybeans (Glycine max) and crayfish (Euastacus spp). Pakistan Journal of Nutrition, 8(10), 1676-1679. https://doi.org/10.3923/pjn.2009.1676.1679

Kavitha, S., \& Parimalavalli, R. (2014). Development and evaluation of extruded weaning foods. European Academic Research, II(4), 5197-5210. https://doi.org/10.1007/978-1-59745-530-5_6

Konyole, S. O., Kinyuru, J. N., Owuor, B. O., Kenji, G. M., \& Onyango, C. A. (2012). Acceptability of amaranth grain-based nutritious complementary foods with dagaa fish (Rastrineobola argentea) and edible termites (Macrotermes subhylanus ) compared to corn soy blend plus among young children / mothers dyads in Western Kenya. Journal of Food Research, 1(3), 111-120. https://doi.org/10.5539/jfr.v1n3p111

Lohia, N., \& Udipi, S. A. (2015). Use of fermentation and malting for development of ready-to-use complementary food mixes. International Journal of Food and Nutritional Sciences, 4(1), 1-4.

Makeri, M. U., Bala, S. M., \& Kassum, A. S. (2011). The effects of roasting temperatures on the rate of extraction and quality of locally-processed oil from two Nigerian peanut ( Arachis hypogea L .) cultivars. African Journal of Food Science, 5(4), 194-199.

Megat, R. M. R., Azrina, A., \& Norhaizan, M. E. (2016). Effect of germination on total dietary fibre and total sugar in selected legumes. International Food Research Journal, 23(1), 257-261. Retrieved from http://www.ifrj.upm.edu.my/23 (01) 2016/(38).pdf

Megat Rusydi, M. R., Noraliza, C. W., Azrina, A., \& Zulkhairi, A. (2011). Nutritional changes in germinated legumes and rice varieties. International Food Research Journal, 18(2), 705-713.

Megazyme International. (2013). Total Dietary Fibre: Assay Procedure K-TDFR 06/14. Ireland.

Mensa-Wilmot, Y., Phillips, R. D., Lee, J., \& Eitenmiller, R. R. (2003). Formulation and evaluation of cereal/legume-based weaning food supplements. Plant Foods for Human Nutrition, 58, 1-14.

Molina, M. R., Braham, J. E., \& Bressani, R. (1983). Some characteristics of whole corn: whole soybean (70:30) and rice: whole soybean (70:30) mixtures processed by simple extrusion cooking. Journal of Food Science, 
48(2), 434-437. https://doi.org/10.1111/j.1365-2621.1983.tb10759.x

Obatolu, V. A., Cole, A. H., \& Maziya-Dixon, B. B. (2000). Nutritional quality of complementary food prepared from unmalted and malted maize fortified with cowpea using extrusion cooking. Journal of the Science of Food and Agriculture, 80(6), 646-650. https://doi.org/10.1002/(SICI)1097-0010(20000501)80:6<646::AID-JSFA509>3.0.CO;2-L

Oke, M. O., \& Workneh, T. S. (2013). A review on sweet potato postharvest processing and preservation technology. African Journal of Agricultural Research, 8(40), 4990-5003. https://doi.org/10.5897/AJAR2013.6841

Omodamiro, R. M., Afuape, S. O., Njoku, C. J., Nwankwo, I. I. M., \& Echendu, T. N. C. (2013). Acceptability and proximate composition of some sweet potato genotypes: Implication of breeding for food security and industrial quality. International Journal of Biotechnology and Food Science, 1(5), 97-101.

Ötles, S., \& Ozgoz, S. (2014). Health effects of dietary fiber. Acta Scientiarum Polonorum Technologia Alimentaria, 13(2), 191-202.

Pan American Health Organization (PAHO) and World Health Organization (WHO). (2001). Guiding principles for complementary feeding of the breastfed child. Global consultation on complementary feeding. Washington, D.C.

Plahar, W. A. A., Okezie, B. O., \& Gyato, C. K. K. (2003). Development of a high protein weaning food by extrusion cooking using peanuts, maize and soybeans. Plant Foods for Human Nutrition, 58(3), 1-12. https://doi.org/10.1023/B:QUAL.0000041157.35549.b3

ProNut-HIV. (2005). Linear programming module of NutriSurvey. Retrieved from http://www.pronutrition.org/archive/200509/msg00027.php

Ramachandra, H. G., \& Thejaswini, M. L. (2015). Extrusion technology: A novel method of food processing. International Journal of Innovative Science, Engineering \& Technology, 2(4), 358-369.

Reddy, M. B., \& Love, M. (1999). The impact of food processing on the nutritional quality of vitamins and minerals. In L. S. Lackson, M. G. Knize, \& L. N. Morgan (Eds.), Impact of processing on food safety. (pp. 99-106). New York: Springer Science+Business Media.

Singh, S., Gamlath, S., \& Wakeling, L. (2007). Nutritional aspects of food extrusion: a review. International Journal of Food Science \& Technology, 42(8), 916-929. https://doi.org/10.1111/j.1365-2621.2006.01309.x

Suri, D. J., Tano-Debrah, K., \& Ghosh, S. A. (2014). Optimization of the nutrient content and protein quality of cereal-legume blends for use as complementary foods in Ghana. Food and Nutrition Bulletin, 35(3), $372-381$.

Tumwebaze, J., Gichuhi, P., Rangari, V., Tcherbi-Narieh, A., \& Bovell-Benjamin, A. (2015). Rheological properties and sugar profile of a maize-based complementary food for Ugandan children 12 to 23 months of age. International Journal of Nutrition and Food Sciences, 4(6), 631-638. https://doi.org/10.11648/j.ijnfs.20150406.15

Ugwuona, F. U., Awogbenja, M. D., \& Ogara, J. I. (2012). Quality evaluation of soy-acha mixes for infant feeding. Idian Journal of Scientific Research, 3(1), 43-50.

WFP. (2004). Fortified blended food: Good manufacturing practice and HACCP principles. A handbook for processors in partnership with the U.N. World Food Programme.

WFP. (2014). Technical specifications for the manufacture of Super Cereal (corn soya blend), Version 14.1.

WHO/UNICEF. (1998). Complementary feeding of young children in developing countries: A review of the current scientific knowledge. WHO/NUT/98.1. Geneva: World Health Organization. https://doi.org/10.1017/CBO9781107415324.004

WHO, UNICEF, \& WORLD BANK GROUP. (2015). Levels and trends in child malnutrition: UNICEF-WHOWorld Bank Group joint child malnutrition estimates. https://doi.org/10.1016/S0266-6138(96)90067-4

Williams, C. L. (1995). Importance of dietary fibre in childhood. Journal of the American Dietetic Assosciation, 95(10), 1140-1149.

\section{Copyrights}

Copyright for this article is retained by the author(s), with first publication rights granted to the journal.

This is an open-access article distributed under the terms and conditions of the Creative Commons Attribution license (http://creativecommons.org/licenses/by/4.0/). 